\title{
Mobile care service for psychiatric urgencies and emergencies: perception of nursing workers
}

\author{
Atendimento móvel às urgências e emergências psiquiátricas: percepção de trabalhadores de enfermagem \\ Atención móvil de urgencias y emergencias psiquiátricas: percepción de los trabajadores de enfermería
}

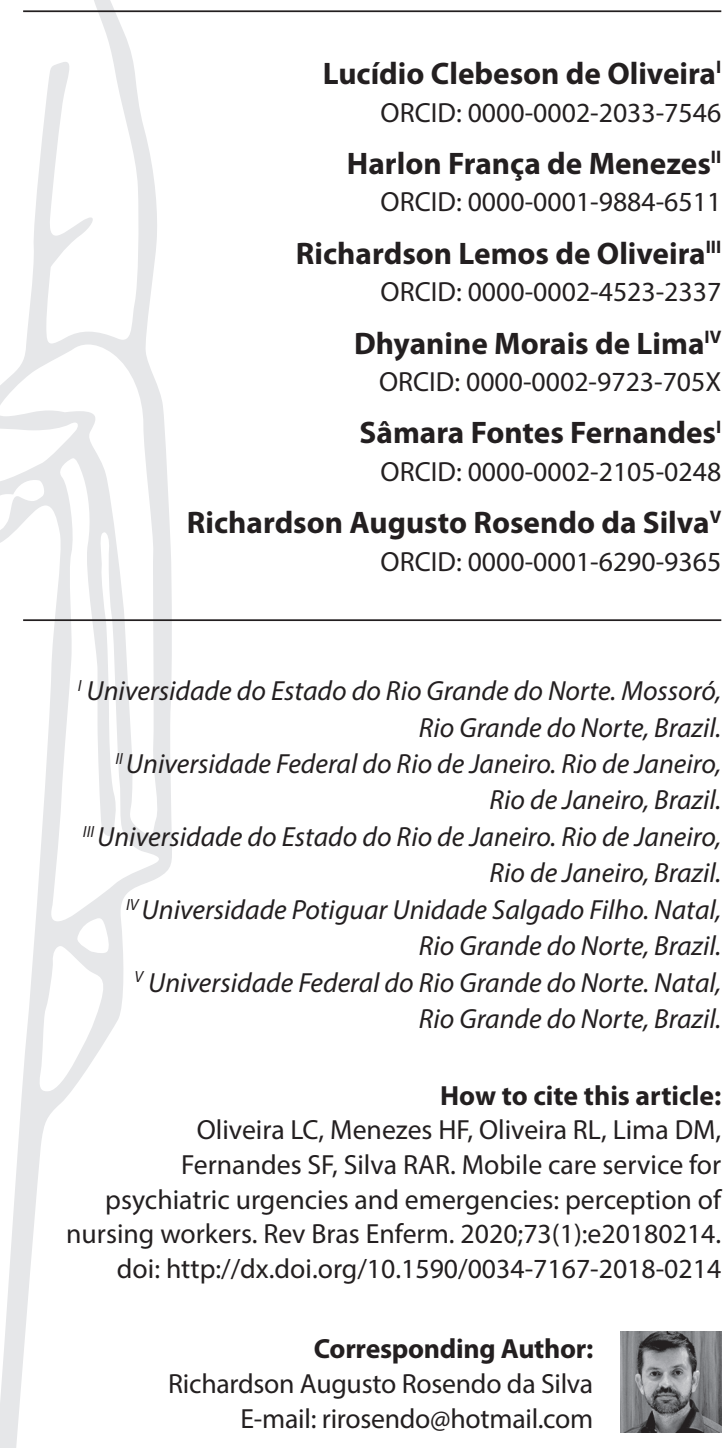

Submission: 04-20-2018 Approval: 06-21-2018

\begin{abstract}
Objective: To understand how the nursing staff perceives the care provided to people in situations of psychiatric urgencies and emergencies in the Mobile Emergency Care Service (SAMU - Serviço de Atendimento Móvel de Urgência). Method: Descriptive and qualitative study conducted in the Northeast region of Brazil with 34 of the SAMU nursing workers. Data were obtained by semi-structured interviews and processed by the Thematic Analysis. Results: The analysis of interviews allowed the identification of three categories: mechanical practice, need for qualification and (de)humanization of care. The results showed that the care offered to users in psychiatric urgency or emergency situations is based on mechanistic and specific actions. Final considerations: Nursing workers perceive that the care for people in situations of psychiatric urgency and emergency in SAMU is mainly based on physical and chemical containment measures, performing a little resolute and dehumanized care and raising the need for professional qualification. Descriptors: Nursing; Mental Health; Psychiatric Emergency Services; Emergency Medical Services; Qualitative Research.
\end{abstract}

\section{RESUMO}

Objetivo: Compreender como os trabalhadores de enfermagem percebem o cuidado às pessoas em situações de urgências e emergências psiquiátricas no Serviço de Atendimento Móvel de Urgência (SAMU). Método: Estudo descritivo, de natureza qualitativa, realizado no Nordeste do Brasil com 34 trabalhadores de enfermagem do SAMU. Os dados foram obtidos por meio de entrevista semiestruturada e tratados pela Análise Temática. Resultados: A análise das entrevistas permitiu a identificação de três categorias: prática mecanicista, necessidade de qualificação e (des)humanização da assistência. Foi possível identificar que o cuidado ofertado aos usuários em situação de urgência ou emergência psiquiátrica é baseado em ações mecanicistas e pontuais. Considerações finais: Os trabalhadores de enfermagem percebem que o cuidado às pessoas em situações de urgências e emergências psiquiátricas no SAMU é baseado principalmente em medidas de contenção física e química, tornando a assistência pouco resolutiva e desumanizada e suscitando a necessidade de qualificação profissional.

Descritores: Enfermagem; Saúde Mental; Serviços de Emergência Psiquiátrica; Atendimento Pré-Hospitalar; Pesquisa Qualitativa.

\section{RESUMEN}

Objetivo: Comprender cómo los trabajadores de enfermería perciben la atención ofertada a personas en situaciones de urgencias y emergencias psiquiátricas en el Servicio de Atención Móvil de Emergencia (SAMU). Método: Estudio descriptivo, de tipo cualitativo, realizado en la región Noreste de Brasil con 34 trabajadores de enfermería del SAMU. Los datos se obtuvieron por medio de entrevista semiestructurada, y se los aplicaron un Análisis Temático. Resultados: El análisis de las entrevistas permitió identificar tres categorías: la práctica mecanicista, la necesidad de calificación y la (des)humanización de la atención. Fue posible identificar que la atención ofertada a los usuarios en situaciones de urgencia o de emergencia psiquiátrica se basa en acciones mecanicistas y puntuales. Consideraciones finales: Los trabajadores de enfermería perciben que la atención ofertada por SAMU a personas en urgencia y emergencia psiquiátrica se basa principalmente en medidas de contención física y química, lo que resulta en una atención poco determinante y deshumanizada, además de apuntar para la necesidad de calificación profesional. Descriptores: Enfermería; Salud Mental; Servicios de Urgencia Psiquiátrica; Servicios Médicos de Urgencia; Investigación Cualitativa. 


\section{INTRODUCTION}

The Brazilian National Policy for Psychosocial Care, regulated by Ordinance No. 3088 of December 23, 2011, establishes the Psychosocial Care Network (RAPS - Rede de Atenção Psicossocial) for people with suffering or mental disorder and with needs arising from the use of crack, alcohol and other drugs, under the Unified Health System (SUS)(1).

In addition, this ordinance is discriminated by wealth solutions, being: Specialized Psychosocial Attention, to the Teaching of Psychosocial Centralization (CAPS) in its different forms; Emergency and Emergency Care Formed, among other points of service, by the Mobile Emergency Care Service (SAMU); Residential Attention of transitory character, formed of points of attention; Strategies for deinstitutionalization, formation of Therapeutic Residences and Psychosocial Rehabilitation ${ }^{(1)}$.

Emergency services have occupied a place at the same time and problematic in RAPS, since in most cases, after emergency care, the individual can be referred for psychiatric hospitalization $^{(2)}$. In general, care is preferred to sedation and to hospital admission when faced with manifestations of a psychic crisis, which strengthens a crisis emergency /hospitalization crisis as if it were a large, if not unique, alternative to represent a crisis $^{(3)}$.

The SAMU (Serviço de Atendimento Móvel de Urgência), as a mobile emergency care service, most of the times, incorporates the agility, functionality and objectivity in its care policy and practice $^{(4)}$. Regarding psychiatric care, commonly, the service continues the execution of repressive medical attitudes, such as physical and chemical restraints performed incorrectly and/or in moments in which they were expendable. This reinforces asylum practices and contradicts the Brazilian Psychiatric Reform ${ }^{(5)}$.

In contrast, the care for people in situations of psychiatric urgency and emergency should be seen as a moment to foster acceptance and understanding of the subjectivity shown during the intensification of psychological distress, promotion of dialogue, intensification of human relations as a therapeutic element, and struggle to build citizenship and social justice for service users ${ }^{(6)}$.

The studies carried out in the field of mental health point out that the theoretical and practical changes produced by this complex process of reorganization of the country's health system point to another no less complex field: that of professional training. The changes brought by the SUS show a number of challenges and it does not seem possible to produce a reorganization of mental health practices without simultaneously interfering with the current training model, considering that these professionals will put this transformation into practice ${ }^{(7-8)}$.

In this sense, it is believed that the study about the way nurses perceive care for people in emergency situations and psychiatric emergencies in SAMU can provide contextualization on the field of mental health, arousing looks for affective, symbolic and subjective aspects, contributing to a professional practice focused on humanized care, making it more compatible with the actions of care and with the specific demands of this group. It is also hoped, with this work, to contribute to the reorientation of RAPS, encouraging new research in the area.

Thus, the present study is justified by the need to know the perceptions of nursing workers about care for people in emergency situations and psychiatric emergencies in SAMU. In this sense, the singularities highlighted by the interviewees in the present research may reveal a rich universe of possibilities to understand how this care is developed within SAMU, essential to broaden discussions of the topic in other scenarios in Brazil, with a view to improving public policies on mental health.

Given this scenario, we asked: How do nursing workers perceive care for people in emergency situations and psychiatric emergencies in SAMU?

\section{OBJECTIVE}

To understand how nursing workers perceive the care for people in situations of psychiatric urgency and emergency in SAMU.

\section{METHOD}

\section{Ethical aspects}

This study was approved by the Human Research Ethics Committee of Universidade Federal do Rio Grande do Norte. All participants signed the informed consent form.

\section{Theoretical and methodological framework}

\section{Type of study}

Descriptive study with qualitative approach, considered appropriate to the objective of the study, because this type of approach seeks to know the perceptions of the subjective data of the individuals, in order to contribute with the expansion of the knowledge of the nursing area in relation to care in the care of the people in situation of urgency and psychiatric emergency and its unfolding in health care ${ }^{(9)}$.

The concept-tool that underlies the study was that of integrality, constitutional and doctrinal principle of sustainability of SUS, considered the greatest challenge for managers and health professionals. To think in integrality is to think of integral care resolutive, from health promotion to healing and rehabilitation ${ }^{(10)}$. Thus, the SUS organization should be responsible for the continuity of care considering the general needs of the people as a whole, not limited to the treatment and/or prevention of their complications. New needs arise throughout life, and the contingencies of such living result in new needs to be recognized, managed, and cared for by health workers. The look of wholeness invites us to think about how complex health care is and how difficult it is to achieve this ideal ${ }^{(10)}$.

\section{Study setting}

The study was conducted at the SAMU headquarters in the city of Mossoró/RN, Northeast of Brazil. The aforementioned service was chosen because it is responsible for attending to users in a situation of urgency and psychiatric emergency, thus responding to the questions and objectives proposed.

\section{Data source}

The study had as population the nursing staff ( 12 nurses and 30 nursing technicians) who worked for the SAMU in the city of 
Mossoró/RN in from October to December 2013. As inclusion criterion, the nursing workers of this service were listed, who worked in direct assistance with emergencies and psychiatric emergencies. Those who were separated because of vacations or medical leave were excluded. Thus, after meeting the criteria described above, the sample was selected, which was made up of 34 nursing workers, nine nurses and 25 nursing technicians who work in SAMU of said municipality investigated.

\section{Data collection and organization}

As data collection instrument, a semi-structured interview guide with open- and closed-ended questions was used. The interviews were carried out at the SAMU headquarters, between October and December of 2013, during the shifts of the professionals, by the principal investigator in a reserved room, free of interruptions, protecting the privacy of the interviewees. All were recorded with the acquiescence of the interviewees and later transcribed in their entirety, with an average duration of 30 minutes. To ensure the confidentiality of the participants, the statements were identified in the results and discussion by the letter " $E$ " and by numbers from 1 to 10 .

\section{Data analysis}

Data were processed by content analysis, in the thematic category, which is defined as a set of communication analysis techniques that obtain, by systematic and objective description procedures of message contents, indicators (quantitative or not) that allow inferring knowledge related to the conditions of production/reception of these messages ${ }^{(11)}$.

In this sense, this analysis developed from three $\operatorname{stages}^{(11)}: 1$ ) pre-analysis: where the floating material field reading, the Corpus constitution and the formulation and reformulation of hypotheses and objectives are performed, where it is resumed the exploratory stage, enabling the correction of interpretive directions or the opening of new inquiries; 2) exploration of the material: the classification operation takes place by the researcher in order to understand the text. In this stage, categories were constructed from the most relevant elements in the interviewees' speeches; 3 ) treatment of the data obtained and interpretation: the treatment of the obtained results and interpretation of the same ones according to the pre-established theoretical framework is developed.

\section{RESULTS}

Considering the sociodemographic characteristics of the nursing professionals in SAMU of Mossoró, most of them were female (67\%), between 46 and 55 years (45\%), married (68\%), had completed high school (60\%), family income around four minimum wages (55\%), two employment relationships (62\%) and had been working between four and five years in this service (70\%).

The SAMU Mossoró was created on November 2, 2005, currently work 42 nursing professionals, 12 nurses and 30 nursing technicians, counting on a fleet of four ambulances.

This service did not adhere to the regionalization process of SAMU in Rio Grande do Norte, serving only the municipality, and has the following mobile units: basic ground life support unit; advanced terrestrial life support unit; motolance; and rapid intervention vehicle. From January to December 2017, around 40 thousand people were assisted in Mossoró. Of this total, there were 22,248 clinical consultations, 3,986 psychiatric, 1,855 pediatric, 793 obstetric, 230 neonatal, 9,605 trauma consultations, and in 5,950 cases the specialty was not informed.

The categories that emerged from the interviewees' own speech related to the care of people in emergencies and psychiatric emergencies at SAMU were: mechanistic practice and need for qualification and (de) humanized care, which are described below.

\section{Mechanistic practice and need for qualification}

The perceptions of the nursing staff clearly showed that the care in psychiatric urgency and emergency is mechanistic and conceptualized as a practice that does not value the components of subjective or affective order that directly influence the disease. This reality became clear in the interviews, considering that mechanized practices are still used.

[...] the service in psychiatric emergency is very mechanical and stressful [...] it ends up not being comprehensive [...] we only get closer when the user is quiet or restrained, it's only then that we can continue the assistance to prevent him of assaulting someone of the staff. (I2)

[...] everything is very mechanical and direct, there is nothing of integrality in the assistance [...] we ask the family if the user is aggressive. If it is violent, the central unit then calls the police to help with the immobilization, so it is easier to restrain the user, then restrained we will refer to the nearest psychiatric hospital [...] at the end of the care the staff gets very emotionally worn out because we see how the family suffers. (I7)

My work is automatic [...] I do not see it as integral [...] if it is a psychiatric user in crisis it is very exhausting [...] we act to get him out of the house or from the street and we take him to a hospital [...] if it is a case of aggression, it is already mechanical ... we must first be careful to ask police and family help to contain it, then to be safe and not have a second victim, then only after that if you can transfer to the service or make any medication prescribed by the doctor. (18)

Faced with the obstacles experienced by nursing workers in their practice related to the lack of an articulated and integrated mental health network, they report that they do not have training in the area of mental health, since it could contribute to the interferences that the work has. which shows the need to work on this theme, since each day the number of users in emergency situations and psychiatric emergency is increasing.

In addition to the obstacles in the care of psychiatric patients, such as the health network that is not articulated and integrated, we are not prepared to serve these users [...] thus, the care will never be complete [...] We have frequent prehospital care the emergencies and psychiatric emergencies specifically never been offered ... what I know of psychiatry was what I saw in college [...] ] I consider that this contributes to the practice of nursing being inhumane ... another 
obstacle in our work are the low salaries and wage inequalities [...] the salary of the doctor is much higher than that of the nurse, leave us discouraged [...] we go out together to attend the psychiatric emergency and the doctor gains four times more. (11)

There are a lot of obstacles in attending to the emergency and psychiatric emergencies in the SAMU, so that it is not comprehensive, first there is no preparation, I only had contact with Psychiatry in the Secondary [...] secondly we do not have the support of the relatives in helping to contain, third, sometimes we have nowhere to take this patient ... To tell you the truth I did not see anything related to the subject or the college, we have frequent trainings and we all did the basic and advanced life support that was offered by the Ministry of Health and we do not even want to have an introduction to the emergencies and psychiatric emergencies ... it also has the issue that the physician is still responsible for the attention to the user and then we have to wait for his order to act, and the kind of training that they end up prescribing often mechanical and inhuman conduits. (I2)

In emergency and psychiatric emergencies specifically there has never been a directed training in SAMU [...] what I know of psychiatric urgency l learned in Graduation [...] here in SAMU we did only the basic and advanced life support course and in it had a module on urgencies and psychiatric emergencies [...] another thing that holds this inhuman work is hierarchical relationships, especially among medical professionals and nursing staff. (14)

\section{(De) humanized care}

An evident aspect of SAMU nursing staff's everyday lives is related to situations that affect inter-subjective assumptions of humanization and integrality, where the prevalence is of actions based on, for example, chemical and mechanical restraint, leaving aside the therapeutic exchanges and listening. Thus, this category is conceptualized as a traditional service, which does not consider the holistic approach and the integrality of the human being.

[...] the SAMU care service to the mentally ill user is inhuman, not comprehensive [...] is a violence to the user [...] practically based on restraint and sedation [...] there is a large abuse of these drugs [...] there should be a better alternative for our work to be more human [...] the psychiatric user is a human being. (I3)

[...] I have witnessed the abusive use of sedatives in psychiatric patients, it is undoubtedly inhuman [...] never dialogue as the user, they soon contain and sedate [...] the fear of being attacked by the patient is great, sometimes we use physical force [...] the service is far from integral. (16)

[...] thinking about the safety of the team and the family, sometimes we end up being a little inhuman, making it difficult to have full attention [...] is to contain and sedate [...] I've seen colleagues until they attacked patients. (I1)

Practitioners demonstrate that the use of physical violence is routine in their everyday lives, and that it plagues the humanitarian aspects of prehospital care.

[...] unfortunately I see no alternative when I go to an aggressive psychiatric patient [...] is to contain and sedate [...] I know that I end up being inhuman, but doing what? [...] I have to use brute force, but even the family understands what it takes. (12)

[...] I have even seen a colleague working out in a physical fight with the patient in crisis [...] the team is not prepared, so the care is inhumane [...] call the police to help with the care and contain the patient is even worse, I have seen very patient beaten and injured. (I8)

\section{DISCUSSION}

Regarding the participants' socio-demographic data, they coincide with data from a survey conducted with nurses working in care services for psychiatric urgency and emergency in São Paulo, since most were women, young adults and single. Moreover, the results of this study are in agreement with the Brazilian nurses' profile, which describes that approximately $90 \%$ of nurses are female and that nursing is one of the ten professions in the health area that contributes to the feminization of work power in the health sector of the country ${ }^{(5)}$.

From the analysis of the testimony, it was verified that the nursing workers in the pre-hospital psychiatric care have a broad view on the phenomenon of their assistance, typifying their various natures, however, markedly added in their meaning the mechanistic practices, the lack of qualification, humanization of care and integral care, verbalized in their speeches.

It can be understood, in general, that the repercussion of the aspects referred by nursing workers, based on the notion that the biomedical model still demonstrates the dependence on techniques, specializations and mechanistic understanding, is shown in the need of contribution of the disciplines of the sciences accurate, social and human, so that guidance can be taken to reach the understanding of the health-disease process, since the factors or elements that each discipline manipulates and consider important, can not be studied in isolation or excluded, that is, they must be integrated because in some way they relate to or influence each other ${ }^{(12)}$.

Studies show that the current of biomedical thinking, based on exclusion, the chronification of users and the violation of citizens' rights, gave rise to political, scientific and social initiatives that brought to the fore a new way of thinking about the health-disease process through of valuing care for the subject ${ }^{(13-14)}$. This movement had as a milestone the beginning of the implementation of substitutive services to the psychiatric hospitals, called CAPS, which today RAPS proposes to reorganize mental health services in an integrated way, expanding and diversifying health actions and equipment and, in order to guarantee access universal care and integral quality care for people in psychological distress.

It is in this sense that it is necessary to seek integrality and to meet the territoriality of care requirement, recommended by SUS, which highlights the role of health care services for the implementation of the basic principles of the Psychiatric Reform for social inclusion, through the Support Centers for Family Health, Offices in the Street, CAPS and emergency services ${ }^{(15)}$.

In the meantime, if there is no integration, there is a risk of repeating the dehumanized, fragmented and focused model of individual biological recovery, with a rigid division of labor and unequal social valuation of the various works, not differing from the context of the psychiatric reform. 
From the introduction of the reflection on integrality, discussions on the relevance of traditional practices addressed in mental health have been intensifying. In this sense, the concept of integrality in mental health services is innovative, since the practices are now conducted according to the subjects' needs, instead of to the disease ${ }^{(16)}$.

These conceptions interfere directly in the production of integral care and comprehensiveness of the Psychosocial Care Network (RAPS - Rede de Atenção Psicossocial), more specifically in the professionals' view on the RAPS. It can be stated that the decision-making process undertaken by SAMU workers is held based on their experience, knowledge and values, bound together in the nucleus of knowledge and practices of the Emergency Medical Service ${ }^{(17)}$.

In the process of deconstructing this whole context, it becomes necessary to expand the scope of intervention of SAMU to an effective rupture with values that still justify segregating practices and conceptions. The study shows that the network and the direction of demand, and the conceptions, bring a fragmented and ineffective flow form. The medical regulation of emergencies is identified as an entry point, together with basic care, and must act as guiding element and computer of the Integral Attention System to the Emergencies, in order to structure the relationship between the various services, as well as qualify the flow of users and establish an open communication channel ${ }^{(17)}$.

On the other hand, with regard to the protocol operation of the SAMU, which should bring both the forms of action and the direction of the demands, some studies affirm that psychiatric services do not always count on capabilities, much less with a directing protocol ${ }^{(8)}$. The authors also show that each physician ends up creating his or her own and this revolves around, once again, concepts of aggressiveness and/or dangerousness, not involving specialized care or involving greater complexity ${ }^{(4,7-8)}$. The study clearly demonstrated the need for professional training to understand the care flows, points of attention and recognition of the RAPS as a whole, as well as the creation of specific referral protocols for users in psychic crisis.

Nurses, participants of the present study, reported having received emergency preparedness and psychiatric emergency only during graduation. However, the data from this current study reveal that there were few possibilities for learning about the psychiatric emergency to perform its prehospital care functions. In this sense, it is reiterated that one of the main challenges for the consolidation process of the Brazilian Psychiatric Reform is in the formation and development of human resources, whose process demands more and more theoretical and technical aspects and attitudes of the workers to act with quality in the service to the users of health services(5).

And it is in this configuration that the Permanent Education in Health presents itself as axis of possibility of reflection and changes of practices in the field of health and, even in Mental Health. Nursing, as a profession that compose the health team, is invited to go beyond the actions of contain, monitor and medicate, which for so many years have summarized their participation in the process of mental health care. In this configuration, the work process, especially of the nursing team, was faced with new demands in the care, in order to value the therapeutic relationship, increasing the capacity to listen, to welcome and to dialogue with the users in search of integral care ${ }^{(18)}$.

In this context, the integrality of care aims to allow contact and acceptance of the psychological distress, presenting different responses from those recommended by the biomedical model, which has the disease as the intervention focus ${ }^{(8)}$. The challenge is to break down as the linear vision for health actions and to embrace a plural range of other professionals for a clinical practice that requires individualization of the subject so that his subjectivity can be heard ${ }^{(9)}$.

Without the theoretical support provided by strategies of permanent education in services, based on criticism and reflection in the teaching / learning process, the tendency of the institutions working in the context of mental health would be the use of the asylum apparatus during the care provided. In this sense, even in the area of health education, it is indispensable to (re) direct curricula and pedagogical practices for the construction of competences aimed at psychosocial attention ${ }^{(7)}$.

However, a study reveals that nurses perceive a gap between the theoretical and practical knowledge developed in their training and the specific knowledge required for their performance in mental health services. However, when asked what they would change in their training, they explain a demand for more psychopathological studies and do not include knowledge and practices defined in the Psychiatric Reform and mental health policy, such as working with groups and territories and strategies of social insertion of users. The study showed that the professional identity of the interviewees is still linked to traditional knowledge and practices, in a hospital-centered perspective and still far from the policy of promoting mental health ${ }^{(19)}$.

The study showed that continuing education is seen as a viable alternative to changes in the workplace because it promotes different forms of education and learning ${ }^{(19-20)}$. Addressing this issue is relevant given the need for continuous training of professionals working in SAMU, since health care protocols are constantly updated. ${ }^{(8)}$ For this reason, the Ministry of Health established the Center for Education in Urgencies, which provides an continuing training for professionals in order to qualify them for the treatment of various types of diseases with which they can come across. In this sense, the existence of scientific evidence about the continuing education in SAMU can direct the decision-making of the professionals involved in the care of psychiatric urgencies ${ }^{(20)}$.

Studies indicate that the Permanent Education in Health is a structural strategy for changes in mechanistic health practices, anchored in the biological model ${ }^{(21)}$. This, in turn, cannot be limited to training and punctual training, but should be a tool for analysis and reflection of the team work process, enabling these professionals to understand the complexity of the situation of psychic crisis and its possibilities of intervention ${ }^{(22-23)}$. Thus, it is necessary to direct the actions from the beginning to the disruption with the paradigm of the emergency clinic $^{(24)}$.

In this process, there is a need to gradually incorporate light technologies related to reception, dialogue and accountability, which contribute to the construction of more human knowledge and practices ${ }^{(25)}$. Without the theoretical support provided by strategies of permanent education in the services, based on criticism 
and reflection in the teaching/learning process, the tendency of the institutions that work in the context of mental health would be the use of the asylum apparatus during the care provided ${ }^{(26)}$.

Thus, it is necessary to turn our attention to the way in which mental health actions are operationalized, contributing to the service redefining its practices and making its intervention power more flexible in psychiatric emergencies ${ }^{(27)}$. In particular, the training of the Permanent Education Nucleus (NEP) of SAMUMossoró may be open to this need and not focus the activities developed in the transmission of knowledge and techniques in a traditionalist perspective of the educational process.

Authors point out that the traditional curricula in health education, mainly in Mental Health, predominantly organized in a disciplinary way, focused on specialization, fragmentation, medicalization and strengthening of the hospital-centered psychiatric paradigm, contribute to a mechanistic and dehumanized practice, linked to the use of psychopharmaceuticals, force and contention ${ }^{(7,28-29)}$.

This study demonstrated that traditional health training and lack of permanent education compromise the quality of the assistance of the SAMU nurses in dealing with the psychiatric crisis, which mainly use mechanistic and dehumanized practices such as strength, mechanical restraint and medication, since they are trained with greater emphasis on traumatic or clinical care ${ }^{(8)}$. In this sense, in the area of health education, it is indispensable to (re) direct curricula and pedagogical practices for the construction of competences aimed at extended psychosocial care ${ }^{(7)}$.

The transformation of care practices to people in situations of urgency and emergency in SAMU must also meet the interests of SUS public administrators (in the cities, states and country) in implementing new management arrangements for the necessary articulation between the substitutive services to the psychiatric hospital, such as Psychosocial Care Centers (CAPS - Centros de Atenção Psicossocial) and Therapeutic Residences (RT - Residências Terapêuticas) with Primary Health Care network ${ }^{(30-31)}$.

This articulation should consist of, therefore, spaces where ways of thinking and acting on mental health can be expressed in agreement with the valuation of subjects with mental illness, their life context and their demands and needs ${ }^{(32)}$.

Therefore, the Matrix Support (MA) is an attempt to qualify the network of mental health care and empowering professionals and users $^{(33)}$. It seeks to ensure specialized back up, through the CAPS teams, to direct assistance to the user, as well as providing technical-pedagogical support to health professionals, equipping them for adequate care for said claim. In addition, the MA seeks to increase the resolubility of mental health actions by proposing a reformulation in the way of organization of services and horizontal relations between the CAPS (specialists) and other health services team, in an interdisciplinary perspective ${ }^{(34)}$.

In this sense, the establishment of support of specialists in mental health for general practitioners of the SAMU through the matriciamento is fundamental for this process, as it provides for co-responsibility, co-management and bonding ${ }^{(35)}$. Longitudinal care, joint responsibility for cases, co-management of an individual therapeutic project, the link established between the different professional categories, as well as the professionals with the people attended presuppose the understanding that the generalists will have specialists support for the care of situations of greater complexity ${ }^{(36)}$. The investment in meetings aiming to explain and achieve adherence to the project becomes necessary. Otherwise, the understanding and rejection will occur through the understanding that the general practitioners of the teams will have to meet another demand, which is usually referred to specialized services ${ }^{(37)}$.

The author points out that the methodology of matrix support can reduce the risks of institutionalization of conducts, as well as iatrogenic behaviors in psychiatric emergencies ${ }^{(38)}$. Thus, there is the possibility of incorporating mental health care in an expanded clinical perspective, through an interdisciplinary and/or transdisciplinary approach. AM in mental health implies the collective construction of work as a process in order to seek the integrality of attention ${ }^{(39)}$. Thus, it generates possibilities of "greater transversality coefficients in the relationships between the professionals of the reference teams, between teams of several services and between professionals and professionals in specialized areas"(40).

In addition, the AM strengthens the spaces of experience exchange and permanent health education, since it has the function of sharing knowledge and building intervention possibilities, contributing to the process of demystification of "mental illness"(41).

It should also be noted that one of the relevant aspects in the practice of nurses working in psychiatric emergency, which contributes to the production of dehumanized and mechanistic health actions, refers to the difficulty of co-responsibility for care and wage inequality in relation to medical category. In general, they use as an argument the lack of autonomy and the submission of nursing work to medical work ${ }^{(42)}$.

The author points out that nurses demonstrate difficulties in defining the work object in the paradigm of Psychiatric Reform, that is, in this mental health team, which defines as subject of intervention the subject-citizen in their psychosocial needs, the nurse is not defined as subject -worker ${ }^{(42)}$. Thus, one can inquire what is the condition of this professional to conduct themselves in relation to a care whose orientation is the social reintegration of the person with mental disorders when he himself does not position himself in the team as a citizen-subject.

In the present study, when the relationship established between the nursing team and the physicians of the SAMU in the production of dehumanized and mechanistic health actions is understood, it is possible to observe the maintenance of the hierarchical relations, mainly among medical professionals and nursing staff, referring to wage inequalities and to the fact that the physician is historically responsible for paying attention to the user.

In addition, it is necessary to reflect on the actions and values that nursing can contribute to the process of reconfiguration of integral psychiatric care, where it is necessary to know the peculiarities of each pathological event, but emphasizing the holistic aspects and thus directing the assistance ${ }^{(2)}$.

In mental health, comprehensiveness can be understood as a compromised action to break down barriers, dismantling the ideal of hospitalization, medicalization, isolation and loss of autonomy as the best form of intervention ${ }^{(7)}$. What is sought is to rescue a more positive concept about madness, demanding that care take 
place in different spaces and demanding an assistance practice that considers the subjectivity and singularity of the subject in psychic suffering in which inclusion, citizenship, autonomy, and solidarity appear as concepts guideline for integral actions ${ }^{(18)}$.

For that, the performance of nurses is crucial for the proper management of the multidisciplinary team and the building process of the emergency care in mental health. Moreover, the need for readjustments in the psychosocial care paradigm and the emphasis on actions about nursing practice have considered the legal aspects of care management offered to the person with mental disorder and his/her family ${ }^{(16)}$.

Therefore, the nurses' performance is essential for the proper management of the multidisciplinary team and the process of constructing emergency care in mental health. In addition, the need for readjustments in the psychosocial care paradigm and emphasis on actions on nursing performance have considered the legal aspects of care management offered to the person with mental disorder and his/her family ${ }^{(42)}$.

From the same point of view, the transformations arising from the deinstitutionalization paradigm and its consequences in the field of mental health, above all from nursing care actions, considering care with an emphasis on singularities, contribute to the principles of citizenship and social reintegration as instruments that confirm and stimulate the qualification of their practice ${ }^{(43)}$.

Thus, it is necessary and necessary for nursing professionals to approach the subject with mental suffering and to allow themselves to learn to care for them according to their history, their subjective pains, their choices, their difficulties and with their - although so provisional and peculiar - conquests ${ }^{(43)}$.

The approaches and elements of the practice of territorial care, proposed by a review study, refer to the diverse elements of the psychosocial field: strategies, principles, professionals' action, territorial resources, citizenship, emancipation of subjects, among others. Thus, territorial practices bring as the only imperative the valuation of the user as a social being, a citizen, autonomous, unique, capable of raising their health levels. To this end, practices must happen from inside the services, that is, in the territory where the users live, through the relation ${ }^{(44)}$.

In this perspective, psychiatric nursing in search of integral health care invests in valuing the context in which users live in their significant social interactions, in the territorial resources necessary for the emancipation and autonomy of the users. The great challenge for psychiatric nursing in search of integral care is to break with historically hospital-centered practices mediated by technical, fragmented and authoritarian procedures centered on "disease" "(44).

Thus, the comprehension of the integrality of mental health care is permeated by the understanding that the subject is a being of wide and different needs that can not be approached in isolation ${ }^{(13)}$. Thus, there is a need for investment in the network of mental health services, both in relation to the creation of services that are opposed to the asylum logic, and in the consolidation of these, so that they act by allowing diverse offerings for a diversity of subjects' demands in psychological distress ${ }^{(12)}$.

In this sense, care should be taken to ensure that health professionals provide comprehensive care, sharing experiences, involving family members and the community ${ }^{(18-19)}$. It becomes necessary to assume the integrality as a guiding axis of new forms of social action in health, of a new form of management of care in health institutions, allowing the emergence of innovative experiences in the incorporation and development of new healthcare technologies. It is necessary to exercise the practice of sharing knowledge and looking at the problems together, in order to take care of it in an integral way ${ }^{(16)}$.

Thus, through the evidence found, it is extremely important to approach the subjects involved in the work process in prehospital care services in mental health, since it is necessary to pay attention to the subjective and unique needs of each individual ${ }^{(19)}$.

Dialogue is a very important tool, since speaking at the right time often alleviates suffering and facilitates professional/user interaction ${ }^{(9)}$, thus reducing the need for the use of contentions, whether physical or chemical, but in reality studied, the opposite happened because patient care is done using restraint and often accompanied by police action.

In this context, the nurses' posture modification that matches the goals of psychiatric reform, considering a holistic approach to care, the individuality of the human being, the context of health and illness in which he is inserted, the interpersonal relationship, permeating coparticipation in the process of rehabilitation and the promotion of self-care as a way of making the subject responsible for their health, self-awareness, self-esteem development and professional skills of the professionals, are fundamental for the Nurse to assume all the roles that the profession requests in order to promote a more humanized and less mechanistic care in an area as sensitive as that of emergency and emergency mental health ${ }^{(7-8)}$.

Finally, it is expected that the SAMU nursing employees working in the municipality investigated, even before confrontations and contradictions in the provision of care to people in situations of psychiatric urgency and emergency, militate in favor of a human and welcoming assistance. For this purpose, they can make use of soft technologies, co-management, matrix support, professional autonomy and rescue of users as social subjects.

\section{Study limitations}

Despite the importance of the results brought by this study and its advances in the area of knowledge, it must be considered within its limitations, among them, it has a sample of professionals who, despite belonging to a large city of the state in area, it certainly does not represent the diversity that can be found in the country. We did not seek to compare the knowledge of inpatient and emergency services professionals.

This study does not intend to exhaust the theme, but opens perspectives for the expansion of new investigations about the aspects that involve the assistance to which the nursing professionals are exposed in the daily routine of emergency care and psychiatric emergency.

\section{Contributions to the field of Nursing, Health or Public Policy}

The study discusses issues on qualification, mechanistic practice and humanization, a current theme in mental health and psychiatry that, apparently, is not easily handled by professionals, 
as well as by common sense due, to the influences of the biomedical model. In this way, the research lends itself to opening the scenario and understanding the professional experience, highlighting the look at the themes that arise in the interviews, allowing a naturalistic generalization of data and the intention of new researches in the area.

\section{FINAL CONSIDERATIONS}

Considering the form of approach undertaken by the SAMU nursing workers, it was perceived that a mechanized care is offered based on coercive measures, being the physical and chemical restraint the main way to assist people in situations of urgency and emergency. The data obtained is different from the guidelines of the Brazilian National Mental Health Policy and the Psychiatric Reform, thus making the care little resolute and dehumanized.

The interviewees pointed out the need for permanent health education in order to carry out appropriate care, because the degree of complexity required for such care is not through hard technologies, but through humanized contact and care.

Despite the efforts made by nursing workers to make care more resilient, a great difficulty was observed in the continuity of care, since there is no network of services organized to serve these clients. Finally, rethinking the assistance provided to these users, guaranteeing the user a humanized service is necessary and emergent.

\section{REFERENCES}

1. Ministério da Saúde (BR). Portaria n 3.088, de 23 de dezembro de 2011. Institui a Rede de Atenção Psicossocial para pessoas com sofrimento ou transtorno mental e com necessidades decorrentes do uso de crack, álcool e outras drogas, no âmbito do Sistema Único de Saúde (SUS) [Internet]. Brasília: Ministério da Saúde; 2011 [cited 2018 Mar 19]. Available from: http://bvsms.saude.gov.br/bvs/saudelegis/ gm/2011/prt3088_23_12_2011_rep.html

2. Leite LS, Rocha KB, Santos LM. A tessitura dos encontros da rede de atenção psicossocial. Trab Educ Saúde. 2018;16(1):183-200. doi: 10.1590/1981-7746-sol00101

3. Chmiel C, Rosemann T, Senn O. Demand and characteristics of a psychiatric 24-hour emergency service performed by mandatory rotation of licensed psychiatrists in Swiss primary care. Patient Prefer Adherence. 2014;8:383-90. doi: 10.2147/PPA.S53950

4. Fraino JA. Mobile nurse practitioner: a pilot program to address service gaps experienced by homeless individuals. J Psychosoc Nurs Ment Health Serv. 2015;53(7):38-43. doi: 10.3928/02793695-20150615-01

5. Vargas D, Soares J, Ponce TD, Oliveira BB. Psychiatric urgency and emergency care nurses: an analysis of their professional and educational profile. Cogitare Enferm. 2017;(22)4:e50704,. doi: 10.5380/ce.v22i4.50704

6. Darbon R, Dalphin C, Prieto N, Cheucle É. The nurse within emergency medical-psychological units. Rev Infirm. 2017;66(230):23-5. doi: 10.1016/j.revinf.2017.02.005

7. Brito $A A C$, Bonfada $D$, Guimarães J. Onde a reforma ainda não chegou: ecos da assistência às urgências psiquiátricas. Physis. 2015;25(4):1293-312. doi: 10.1590/S0103-73312015000400013

8. Oliveira LC, Silva RAR. Knowledge and practices in urgent and emergency psychiatric care. Rev Enferm UERJ. 2017;25:107-26. doi: 10.12957/ reuerj.2017.10726

9. Minayo MCS. O desafio do conhecimento: pesquisa qualitativa em saúde. 13a ed. São Paulo: Hucitec; 2013.

10. Antunes MJM, Guedes MVC. Integralidade nos Processos Assistenciais na Atenção Básica. In: Garcia TR, Egry EY, organizadoras. Integralidade da atenção no SUS e Sistematização da Assistência de Enfermagem. Porto Alegre: Artmed; 2010. p. 19-28.

11. Bardin L. Análise de conteúdo. São Paulo: Edições 70; 2011.

12. Baeta S MF. Cultura y modelo biomédico: reflexiones en el proceso de salud enfermedad. Comunidad Salud [Internet]. 2015 [cited 2018 Mar 09];13(2):81-4. Available from: http://ve.scielo.org/scielo.php?script=sci_arttext\&pid=S1690-32932015000200011

13. Bhattacharyya R. The development of mental hospitals in West Bengal: a brief history and changing trends. Indian J Psychiatry. 2018;60(Suppl 2):S198-S202. doi: 10.4103/psychiatry.IndianJPsychiatry_432_17

14. Zeferino MT, Cartana MHF, Fialho MB, Huber MZ, Bertoncello KCG. Health workers' perception on crisis care in the Psychosocial Care Network. Esc Anna Nery. 2016;20(3):e20160059. doi: 10.5935/1414-8145.20160059

15. Oliveira EC, Medeiros AT, Trajano FMP, Chaves Neto G, Almeida SA, Almeida LR. Mental health care in the territory: conceptions of primary health care professionals. Esc Anna Nery. 2017;21(3):e20160040. doi: 10.1590/2177-9465-ean-2017-0040

16. Cardoso MRO, Oliveira PTR, Piani PPF. Práticas de cuidado em saúde mental na voz dos usuários de um Centro de Atenção Psicossocial do estado do Pará. Saúde Debate. 2016;40(109):86-99. doi: 10.1590/0103-1104201610907

17. Bastos FJS, Dutra CDC, Silva JLA, Pacheco KC, Silva TN. Saúde mental no atendimento pré-hospitalar móvel: Concepções de profissionais. Rev Port Enferm Saúde Ment. 2016;(spe.4):17-24. doi: 10.19131/rpesm.0136

18. Grundy AC, Walker L, Meade O, Fraser C, Cree L, Bee P, et al. Evaluation of a co-delivered training package for community mental health professionals on service user- and carer-involved care planning. J Psychiatr Ment Health Nurs. 2017;24(6):358-66. doi: 10.1111/jpm.12378

19. Souza MC, Afonso MLM. Saberes e práticas de enfermeiros na saúde mental: desafios diante da Reforma Psiquiátrica. 
Gerais, Rev Interinst Psicol [Internet]. 2015 [cited 2018 Mar 12];8(2):332-47. Available from: http://pepsic.bvsalud.org/scielo. php?script=sci_abstract\&pid=S1983-82202015000300004\&lng=pt\&nrm=iso

20. Tobase L, Peres HHC, Gianotto-Oliveira R, Smith N, Polastri TF, Timerman S. The effects of an online basic life support course on undergraduate nursing students' learning. Int J Med Educ. 2017;8:309-13. doi: 10.5116/ijme.5985.cbce

21. Campos KFC, Sena RR, Silva KL. Permanent professional education in healthcare services. Esc Anna Nery. 2017;21(4):e20160317. doi: 10.1590/2177-9465-ean-2016-0317

22. Marcolino TQ, Fantinatti EN, Gozzi APNF. Comunidade de prática e cuidado em saúde mental: uma revisão sistemática. Trab Educ Saúde. 2018;16(2):643-58. doi: 10.1590/1981-7746-sol00112

23. Abrahão AL, Azevedo FFM, Gomes MPC. A produção do conhecimento em saúde mental e o processo de trabalho no centro de atenção psicossocial. Trab Educ Saúde. 2017;15(1):55-71. doi: 10.1590/1981-7746-sol0004

24. Almeida AB, Nascimento ERP, Rodrigues J, Zeferino MT, Souza AIJ, Hermida PMV. Mobile emergency medical services in the psychological crisis and the psychosocial paradigm. Texto Contexto Enferm. 2015;24(4):1035-43. doi: 10.1590/0104-0707201500003580014

25. Almeida AB, Nascimento ERP, Rodrigues J, Schweitzer G. Intervention in situations of psychic crisis: challenges and suggestions of a prehospital care staff. Rev Bras Enferm. 2014;67(5):708-14. doi: 10.1590/0034-7167.2014670506

26. Bispo Júnior JP, Moreira DC. Continuing education and matrix support: training, experience, and practices of health professionals in the Centers for the Support of Family Health and the supported teams. Cad Saúde Pública. 2017;33(9):e00108116. doi: 10.1590/0102-311x00108116

27. Almeida $A B$, Aciole GG. Network management and institutional support: pathways in assembling mental health networks within the regional scenario of the National Health System (SUS). Interface (Botucatu). 2014;18(Suppl 1):971-81. doi: 10.1590/1807-57622013.0371

28. Vasconcelos MFF, Nicolotti CA, Silva JF, Pereira SMLR. In-between policies (CEH - Continuing Education in Health and NHP - Humanization National Policy): towards a way to educate in/ for the Brazilian National Health System (SUS). Interface (Botucatu). 2016;20(59):981-91. doi: 10.1590/1807-57622015.0707

29. O'Dwyer G, Mattos RA. Integral Care and Attention to Emergency: the mobile emergency care service in the State of Rio de Janeiro. Saúde Soc. 2013;22(1):199-210. doi: 10.1590/S0104-12902013000100018

30. Hirdes A, Scarparo HBK. The maze and the minotaur: mental health in primary health care. Ciênc Saúde Colet. 2015;20(2):383-93. doi: $10.1590 / 1413-81232015202.12642013$

31. Ortiga AMB, Lacerda JT, Natal S, Calvo MCM. Avaliação do Serviço de Atendimento Móvel de Urgência em Santa Catarina, Brasil. Cad Saúde Pública. 2016;32(12):e00176714. doi: 10.1590/0102-311x00176714

32. Willrich JQ, Kantorski LP, Antonacci MH, Cortes JM, Chiavagatti FG. Avaliação do Serviço de Atendimento Móvel de Urgência em Santa Catarina, Brasil. Rev Bras Enferm. 2014;67(1):97-103. doi: 10.1590/0102-311x00176714

33. Ballarin MLGS, Blanes LS, Ferigato SH. Matrix support: a study on the perspective of mental health professionals. Interface (Botucatu). 2012;16(42):767-78. doi: 10.1590/S1414-32832012000300014

34. Dantas NF, Passos ICF. Apoio matricial em saúde mental no SUS de Belo Horizonte: perspectiva dos trabalhadores. Trab Educ Saúde. 2018;16(1):201-20. doi: 10.1590/1981-7746-sol00097

35. Hirdes A. A perspectiva dos profissionais da Atenção Primária à Saúde sobre o apoio matricial em saúde mental. Ciênc Saúde Colet. 2015;20(2):371-82. doi: 10.1590/1413-81232015202.11122014

36. Iglesias A, Avellar LZ. The psychologist's contribution to the matrix support in mental health. Psicol Ciênc Prof. 2016;36(2):364-79. doi: 10.1590/1982-3703001372014

37. Hirdes A, Silva MKR. Apoio matricial: um caminho para a integração saúde mental e atenção primária. Saúde Debate. 2014;38(102):582-92. doi: 10.5935/0103-1104.20140054

38. Amaral CEM, Torrenté MON, Torrenté M, Moreira CP. Matrix support in Mental Health in primary care: the effects on the understanding and case management of community health workers. Interface (Botucatu). 2018;22(66):801-12. doi: 10.1590/1807-57622017.0473

39. Jorge MSB, Diniz AM, Lima LL, Penha JC. Matrix support, individual therapeutic project and production in mental health care. Texto Contexto Enferm. 2015;24(1):112-20. doi: 10.1590/0104-07072015002430013

40. Lima M, Dimenstein M. O apoio matricial em saúde mental: uma ferramenta apoiadora da atenção à crise. Interface (Botucatu). 2016;20(58):625-35. doi: 10.1590/1807-57622015.0389

41. Severo AKS, L'Abbate S, Campos RTO. A supervisão clínico-institucional como dispositivo de mudanças na gestão do trabalho em saúde mental. Interface (Botucatu). 2014;18(50):545-56. doi: 10.1590/1807-57622013.0520

42. Coates D. Service models for urgent and emergency psychiatric care: an overview. J Psychosoc Nurs Ment Health Serv. 2018;56(8):23-30. doi: $10.3928 / 02793695-20180212-01$

43. Dias MGPF, Vargas D. Psychiatric nurses' attitudes towards violent behaviour: a brazilian study. Issues Ment Health Nurs. 2018;39(8):687-92. doi: 10.1080/01612840.2017.1422198

44. Dutra VFD, Oliveira RMP. Revisão integrativa: as práticas territoriais de cuidado em saúde mental. Aquichan. 2015;15(4):529-40. doi: 10.5294/ aqui.2015.15.4.8 